\title{
Polyunsaturated fatty acid receptors, GPR40 and GPR120, are expressed in the hypothalamus and control energy homeostasis and inflammation
}

Nathalia R. V. Dragano ${ }^{1}$, Carina Solon ${ }^{1}$, Albina F. Ramalho ${ }^{1}$, Rodrigo F. de Moura', Daniela S. Razolli', Elisabeth Christiansen², Carlos Azevedo ${ }^{2}$, Trond Ulven ${ }^{2}$ and Licio A. Velloso ${ }^{1,3^{*}}$

\begin{abstract}
Background: The consumption of large amounts of dietary fats is one of the most important environmental factors contributing to the development of obesity and metabolic disorders. GPR120 and GPR40 are polyunsaturated fatty acid receptors that exert a number of systemic effects that are beneficial for metabolic and inflammatory diseases. Here, we evaluate the expression and potential role of hypothalamic GPR120 and GPR40 as targets for the treatment of obesity.

Methods: Male Swiss (6-weeks old), were fed with a high fat diet (HFD, 60\% of kcal from fat) for 4 weeks. Next, mice underwent stereotaxic surgery to place an indwelling cannula into the right lateral ventricle.

intracerebroventricular (icv)-cannulated mice were treated twice a day for 6 days with $2.0 \mu \mathrm{L}$ saline or GPR40 and GPR120 agonists: GW9508, TUG1197, or TUG905 (2.0 L, 1.0 mM). Food intake and body mass were measured during the treatment period. At the end of the experiment, the hypothalamus was collected for real-time PCR analysis.

Results: We show that both receptors are expressed in the hypothalamus; GPR120 is primarily present in microglia, whereas GPR40 is expressed in neurons. Upon intracerebroventricular treatment, GW9508, a non-specific agonist for both receptors, reduced energy efficiency and the expression of inflammatory genes in the hypothalamus. Reducing GPR120 hypothalamic expression using a lentivirus-based approach resulted in the loss of the anti-inflammatory effect of GW9508 and increased energy efficiency. Intracerebroventricular treatment with the GPR120- and GPR40-specific agonists TUG1197 and TUG905, respectively, resulted in milder effects than those produced by GW9508.

Conclusions: GPR120 and GPR40 act in concert in the hypothalamus to reduce energy efficiency and regulate the inflammation associated with obesity. The combined activation of both receptors in the hypothalamus results in better metabolic outcomes than the isolated activation of either receptor alone.
\end{abstract}

Keywords: GPR40, GPR120, Obesity, Hypothalamic inflammation

\footnotetext{
* Correspondence: lavelloso.unicamp@gmail.com

'Laboratory of Cell Signaling and Obesity and Comorbidities Research

Center, University of Campinas, Campinas, SP 13084-970, Brazil

${ }^{3}$ Laboratory of Cell Signaling, University of Campinas, Rua Cinco de Junho,

350, Cidade Universitária, Campinas, SP 13083-877, Brazil

Full list of author information is available at the end of the article
} 


\section{Background}

The consumption of large amounts of dietary fats is one of the most important environmental factors contributing to the development of obesity and metabolic disorders [1-3]. Long-chain saturated fatty acids trigger inflammation through the activation of toll-like receptor- 4 and the induction of endoplasmic reticulum stress [4-6]. The low-intensity inflammation generated in this context can act both systemically and on selected anatomical regions to affect insulin and leptin actions [7], insulin production [8, 9], lipid metabolism [10], blood pressure [11], longevity [12], and a number of other parameters involved in the regulation of wholebody energy homeostasis.

Because of the role played by metabolic inflammation in the pathogenesis of insulin and leptin resistance, it has been proposed that approaches leading to the attenuation of inflammation could have a beneficial impact on conditions such as obesity, type 2 diabetes, dyslipidemia, and hypertension [13-15]. In fact, genetic and pharmacological approaches aimed at reducing inflammation have produced encouraging outcomes in various experimental models $[9,14]$. In addition, a recent clinical trial targeted the inhibitor of kappa kinase (IKK) using salsalate, resulting in a significant reduction of glycated hemoglobin levels in patients with type 2 diabetes [16].

Studies have identified the polyunsaturated fatty acid (PUFA) receptors GPR120 and GPR40 as attractive potential targets for the treatment of insulin resistance [17-20]. The activation of GPR120 by PUFAs or synthetic ligands engages an atypical signaling system that attenuates metabolic inflammation in obesity and type 2 diabetes [21]. A recent study has reported the beneficial effect of a synthetic agonist of GPR120 in improving glucose intolerance and hepatic steatosis in an animal model of diet-induced obesity [22]. In addition, a number of studies have reported the potential benefits of systemically targeting GPR40 in type 2 diabetes [23, 24].

A great advance in the field was achieved in 2009 when $\mathrm{Oh}$ and co-workers [18] described a completely new anti-inflammatory mechanism involving the action of PUFAs through GPR120. Upon ligand binding, GPR120 recruits $\beta$-arrestin-2, leading to the internalization of the receptor/regulatory protein complex. The internalized $\beta$-arrestin- 2 binds to TAB1 and inhibits its

Table 1 Macronutrient composition of diets

\begin{tabular}{lllll}
\hline & Chow diet & & HFD & \\
\hline Macronutrients & $\mathrm{g} / 100 \mathrm{~g}$ & Kcal\% & $\mathrm{g} / 100 \mathrm{~g}$ & Kcal\% \\
Protein & 20 & 80 & 20 & 80 \\
Carbohydrates & 62 & 248 & 45 & 180 \\
Lipids & 4 & 36 & 35 & 315 \\
Kcal/100 g & & 364 & & 575 \\
\hline
\end{tabular}

binding to TAK1, which results in the inhibition of its activity. TAK1 is a point of convergence for TNF- $\alpha$ and TLR4 signal transduction, and its inhibition impairs the progression of the signal toward JNK and IKK activation, which results in the inhibition of inflammation [18]. In a recent study, the same group reported beneficial metabolic effects of a small molecule that acts as a specific agonist for GPR120 [22]. Obese mice treated with this molecule exhibit improved glucose tolerance and decreased hepatic steatosis accompanied by a reduction of the metabolic inflammation phenotype, indicating GPR120 is an attractive potential target for the treatment of obesity-associated metabolic disorders.

A number of studies have also shown the beneficial metabolic effects of GPR40 activation [20, 25, 26]. This receptor is highly expressed in pancreatic $\beta$-cells and, upon activation by PUFAs, it increases glucose-induced insulin secretion [20]. In addition, it has been shown that GPR40 expressed in intestinal $\mathrm{L}$ and $\mathrm{K}$ cells induces GLP1 and GIP secretion, providing yet another stimulus for insulin secretion [27]. Although the mechanisms of action of GPR40 are less understood than those of GPR120, studies have shown that the induction of $\mathrm{Ca}^{++}$ mobilization and activation of CREB may play important roles in some of the effects of this pathway [28]. Thus, the potential therapeutic usefulness of agonists for GPR40 is considered relevant [24].

As an attempt to advance understanding of the mechanisms underlying the beneficial metabolic effects of the activation of GPR120 and GPR40, we decided to evaluate their expression and function in the hypothalamus. We show that GPR120 was predominantly expressed in microglia, whereas GPR40 was predominantly expressed in neurons. Furthermore, their activation reduced obesity-associated hypothalamic inflammation and reduced whole-body energy efficiency.

\section{Methods \\ GPR120 and GPR40 synthetic agonists}

GW9508 was purchased from Tocris Bioscience (Ellisville, MO, USA). TUG905 [29] and TUG1197 [30] were synthesized as previously described.

\section{Chemicals and reagents}

All of the reagents for SDS-polyacrylamide gel electrophoresis and immunoblotting were from Bio-Rad (Richmond, CA, USA). HEPES, phenylmethylsulfonyl fluoride, aprotinin, dithiothreitol, Triton X-100, Tween 20, glycerol, and bovine serum albumin (fraction V) were purchased from Sigma Chemical Co. (St. Louis, MO, USA). The antibodies against GPR120 (sc99105), GPR40 (sc32905), neuropeptide-Y (NPY) (sc133080), proopiomelanocortin (POMC) (sc18263), Iba1 (sc28530), $\beta$-arrestin-2 (sc13140), vimentin (sc373717), insulin-like growth factor binding protein-2 (IGFBP2) 

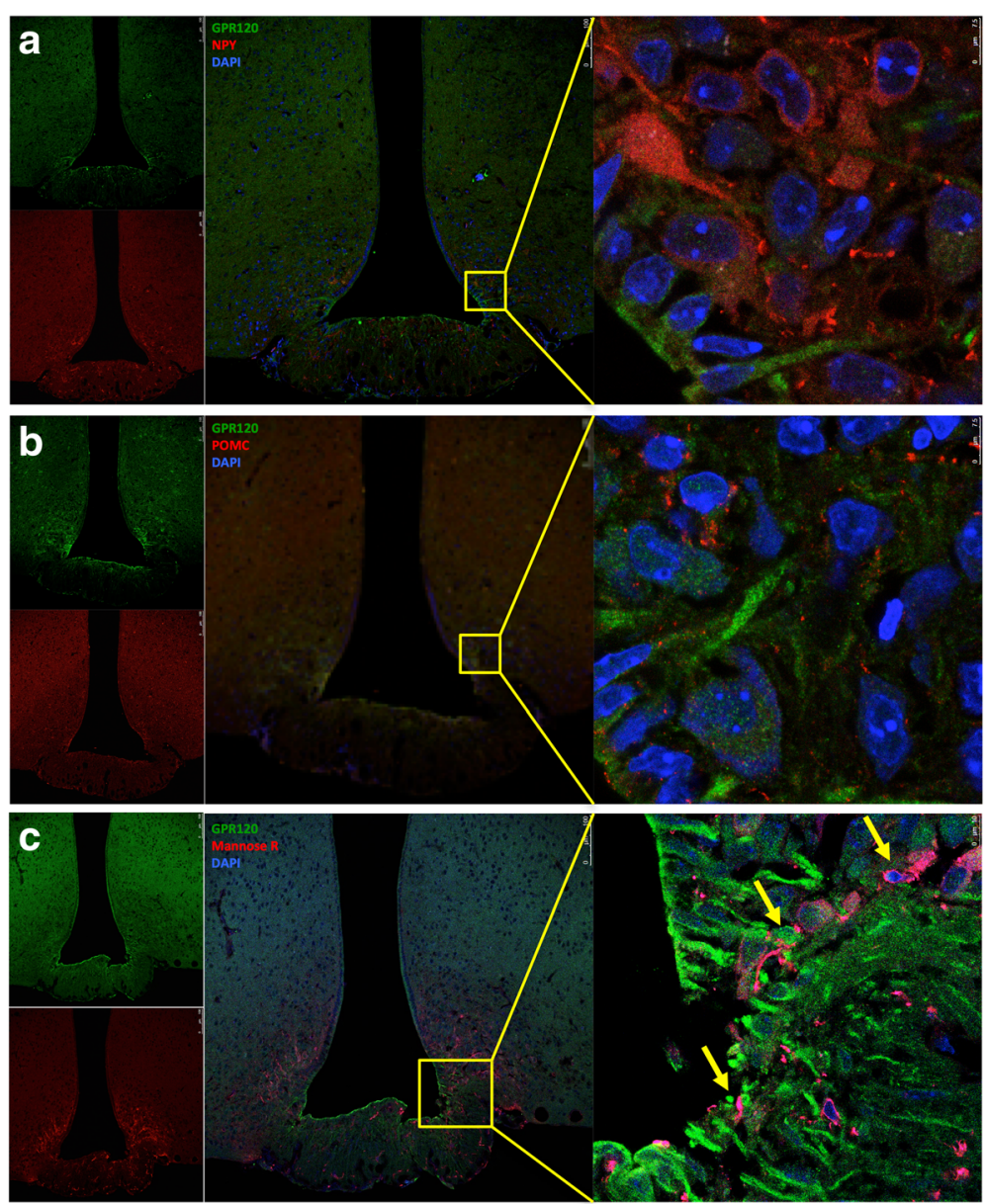

Fig. 1 Cellular distribution of GPR120 in the hypothalamus of mice. Tissue sections ( $5.0 \mu \mathrm{m})$ were prepared from the hypothalamic region of lean Swiss mice and were evaluated by indirect immunofluorescence staining using antibodies against GPR120 (a-c, green), NPY (a, red), POMC (b, red), and mannose receptor (c, red). Nuclei were stained with DAPI (blue). In the captions, the arrows indicate cells co-expressing GPR120 and mannose receptor (c). Images are representative of three independent experiments

(sc365368), and $\mathrm{p}-\mathrm{IKK} \alpha / \beta$ (Thr 23) (sc21660) were from Santa Cruz Biotechnology (Santa Cruz, CA, USA). The $\alpha-$ tubulin (T5168) antibody was from Sigma-Aldrich (St. Louis, MO, USA). The antibodies against mannose receptor (ab8918) and beta-actin (ab8227) were from Abcam (Cambridge, MA, USA). The reagents for chemiluminescence labeling of proteins in immunoblots were from Amersham (Aylesbury, UK). Fluorescein-isothiocyanate (FITC)-conjugated anti-rabbit (sc2012), FITC-conjugated anti-goat (sc2024), rhodamine-conjugated anti-rabbit (sc2091), and rhodamine-conjugated anti-goat (sc094) antibodies were from Santa Cruz Biotechnology (Santa Cruz, CA, USA). Reagents for real-time polymerase chain reaction (PCR) analysis were from Invitrogen (Carlsbad, CA, USA) and Applied Biosystems (Foster City, CA, USA). Primers for tumor necrosis factor-alpha (TNF- $\alpha$ ) (Mm00443258_m1), interleukin-1 beta (IL1 $\beta$ ) (Mm00434228_m1), interleukin-6 (IL6) (Mm00446190_m1), interleukin-10 (IL10) (Mm01288386_m1), GPR120 (Mm00726193_m1), GPR40
(Mm00809442_s1), peroxisome proliferator activator gamma coactivator 1 alpha (PGC1 $\alpha)$ (Mm00447183_m1), uncoupling protein-1 (UCP1) (Mm01244861_m1), cytochrome c (Mm01621044_g1), and glyceraldehyde-3phosphate dehydrogenase (GAPD) (\#4352339E) were obtained from Applied Biosystems.

\section{Experimental animals}

Male Swiss mice originally imported from the Jackson Laboratory and currently bred at the University of Campinas Breeding Center were used in the study. The animals were maintained at $21 \pm 3{ }^{\circ} \mathrm{C}$ on a 12 -h artificial light/dark cycle and were housed in individual cages. At the fifth week of life, mice were randomly assigned to either a standard rodent chow diet (Chow) or high-fat diet (HFD, 60\% of energy value from fat, Table 1, at the end of the document text file.) for 4 weeks or 10 weeks, depending on the protocol. 

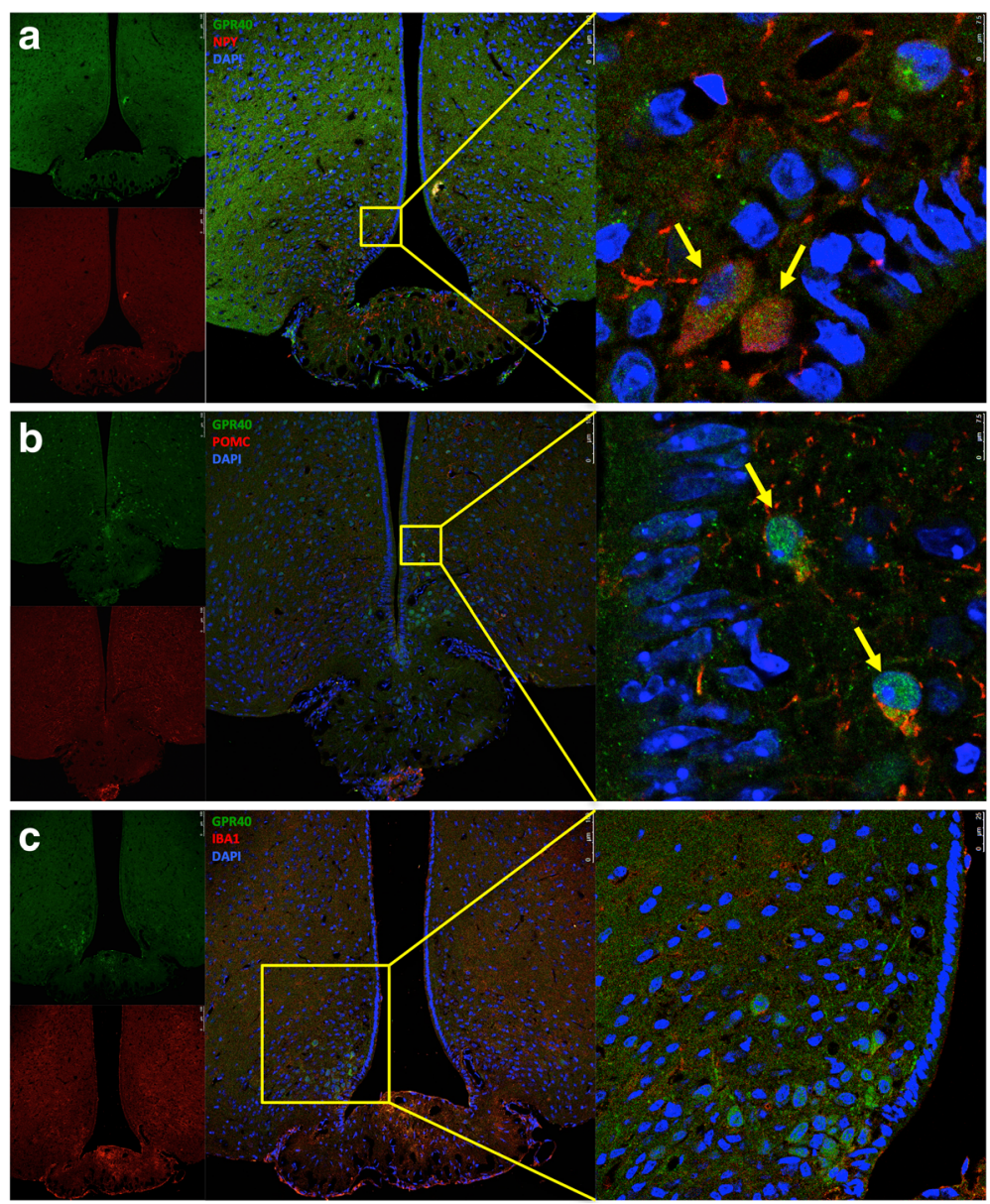

Fig. 2 Cellular distribution of GPR40 in the hypothalamus of mice. Tissue sections (5.0 $\mu \mathrm{m}$ ) were prepared from the hypothalamic region of lean Swiss mice and were evaluated by indirect immunofluorescence staining using antibodies against GPR40 (a-c, green), NPY (a, red), POMC (b, red), and Iba1 (c, red). Nuclei were stained with DAPI (blue). In the captions, the arrows indicate cells co-expressing GPR40 and NPY (a), and GPR40 and POMC (b). Images are representative of three independent experiments

\section{Experimental protocols}

For the evaluation of GPR120 and GPR40 expression in the white adipose tissue, liver, intestine, frontal cortex, occipital cortex, hippocampus, and hypothalamus, mice were fed for 9 weeks on chow and then employed for RNA extraction. To assess GPR120 signal transduction, mice fed a HFD for 4 weeks were anesthetized and subjected to acute lateral ventricle hypothalamic microinjection of $2.0 \mu \mathrm{L}$ of vehicle or GW9508 (1.0 mM), using a Stoelting stereotaxic apparatus set on the following coordinates: anteroposterior, $0.34 \mathrm{~mm}$; lateral, $1.0 \mathrm{~mm}$; and depth, $2.2 \mathrm{~mm}$. After $90 \mathrm{~min}$, the hypothalamus was removed, and protein or RNA extracts were utilized in immunoprecipitation and western blot experiments or realtime PCR analysis, respectively. In another set of experiments, mice were randomly assigned to chow or a HFD for 4 weeks; subsequently, mice were positioned in a Stoelting stereotaxic apparatus to place a cannula in the lateral ventricle using the stereotaxic coordinates described above. Correct positioning of the cannula was tested 5 days after cannulation by evaluation of the thirst response elicited by intracerebroventricular (icv) angiotensin II $\left(10^{-6} \mathrm{M}\right)$. Icv-cannulated mice were treated twice a day for 6 days with $2.0 \mu \mathrm{L}$ of vehicle, GW9508 (1.0 mM), TUG1197 (1.0 mM), or TUG905 (1.0 mM). Treatments were administered at 8 am and $5 \mathrm{pm}$. Food intake and body mass were measured during the treatment period. In each group, some mice were randomly selected for indirect calorimetry and spontaneous physical activity measurements. At the end of the experiment, the hypothalamus was collected for real-time PCR analysis.

\section{Cell culture}

The neuronal cell line mHypoA 2/29 CLU189 (CLU189) and the microglial cell line BV2 were cultivated to $70 \%$ confluence in Dulbecco's modified Eagle's medium (DMEM) containing $25 \mathrm{mM}$ glucose and 10\% fetal 

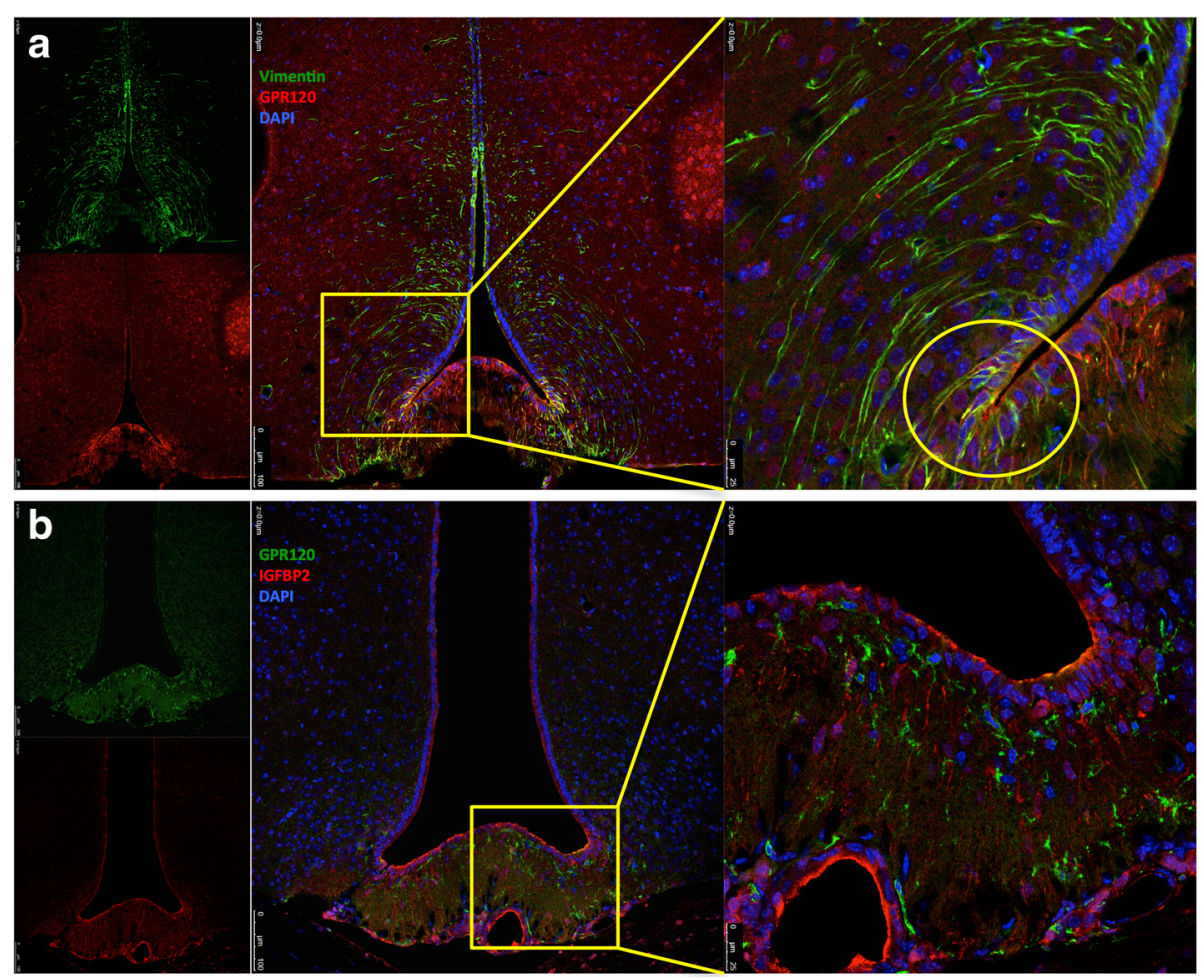

Fig. 3 Cellular distribution of GPR120 in the hypothalamus of mice. Tissue sections (5.0 $\mu \mathrm{m})$ were prepared from the hypothalamic region of lean Swiss mice and were evaluated by indirect immunofluorescence staining using antibodies against GPR120 (a-b, red in $A$ and green in B), vimentin (a, green), and IGFBP2 (b, red). Nuclei were stained with DAPI (blue). In the captions, the yellow circle indicates region with cells co-expressing GPR120 and vimentin (a). Images are representative of three independent experiments

bovine serum. Both cell lines were treated with GW9508 $(100 \mu \mathrm{M})$, TUG1197 $(100 \mu \mathrm{M})$, and TUG905 $(100 \mu \mathrm{M})$ for $1 \mathrm{~h}$ prior to lipopolysaccharide (LPS) $(100 \mathrm{ng} / \mathrm{mL})$ treatment for $10 \mathrm{~min}$ and then subjected to western blot analysis. The doses of the agonists were selected following a dose response experiment.

\section{Lentivirus efficiency}

Five commercially available shRNA-encoding lentivirus plasmids to GPR120: LV1 (NM_181748 1-123s1c1), LV2 (NM_181748 1-816s1c1), LV3 (NM_181748 1-852s1c1), LV4 (NM_181748 1-1105s1c1), and LV5 (NM_181748 11253s1c1), and a scrambled shRNA control plasmid (SHC016V 11051235 MN) (Sigma-Aldrich) were tested in the CLU189 cell line to determine the effectiveness of each shRNA-mediated GPR120 knockdown. GPR120 silencing was evaluated in cell lysates by western blot analysis.

\section{Hypothalamic lentivirus delivery}

Hypothalamic delivery of the lentivirus was performed in Swiss mice after 4 weeks on a HFD. Mice were placed in a Stoelting stereotaxic apparatus for bilateral hypothalamic injection of $1.0 \mu \mathrm{L}$ of lentivirus using a Hamilton syringe linked to a 30 -gauge needle. The coordinates were adjusted to target the arcuate nucleus as follows: anteroposterior, $-1.7 \mathrm{~mm}$; lateral, $0.3 \mathrm{~mm}$; dorsoventral, $-5.5 \mathrm{~mm}$. After the lentivirus infection, body mass and food intake were recorded over 10 weeks. In the eigth and ninth experimental weeks, the animals were subjected to an intraperitoneal glucose tolerance test and an intraperitoneal insulin tolerance test. At the end of the tenth experimental week, a cannula was placed in the lateral ventricle (as previously described), and the mice were treated twice a day for 6 days with $2.0 \mu \mathrm{L}$ of vehicle or GW9508 $(1.0 \mathrm{mM})$. Finally, the hypothalamus was collected for analysis.

\section{Intraperitoneal glucose tolerance test (ipGTT) and insulin tolerance test (iplTT)}

An Intraperitoneal glucose tolerance test (ipGTT)and an insulin tolerance test (ipITT) were performed on fooddeprived $(6 \mathrm{~h})$ non-anesthetized mice. Blood glucose levels were measured with an OptiumTM mini (Abbott Diabetes Care, Alameda, CA, USA) handheld glucometer using appropriate test strips. For the ipGTT, a solution of $20 \%$ glucose $(2.0 \mathrm{~g} / \mathrm{kg}$ body weight $)$ was administered into the peritoneal cavity. Blood samples were collected from the tail vein at 30, 60, 90, and 120 min post-glucose administration for the determination of glucose concentrations. The area under the 
a

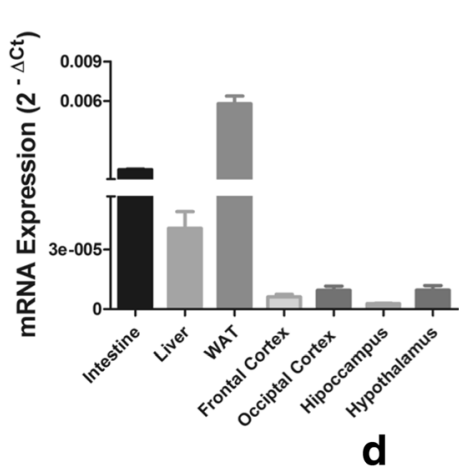

b

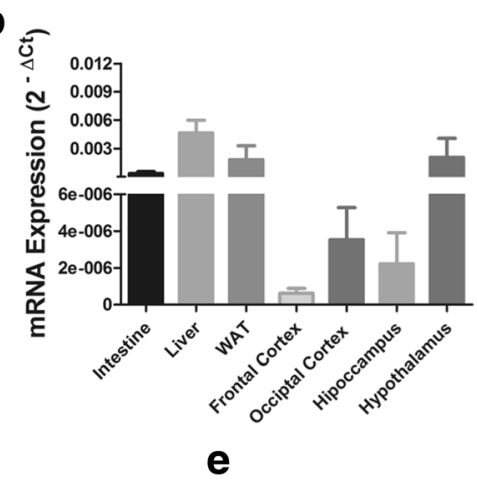

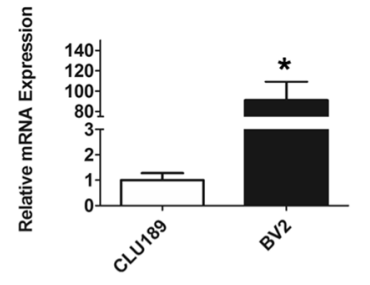
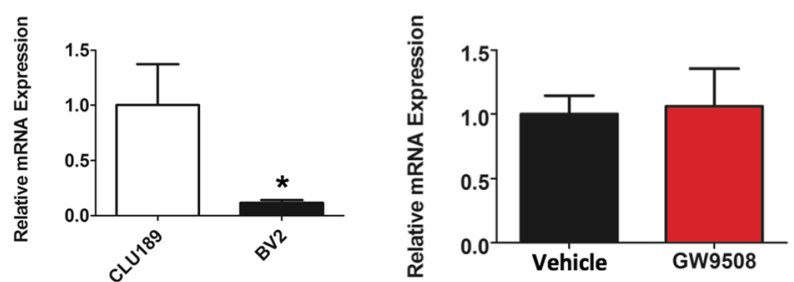

f

IB: GPR120

IB: $\beta$-Arrestin 2

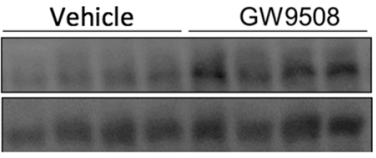

g
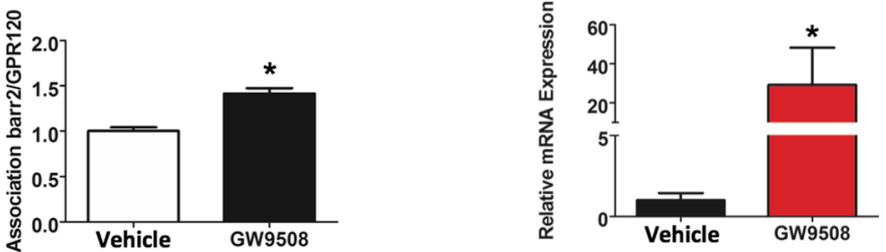

Fig. 4 Expression and activation of GPR120 and GPR40. The expression of GPR120 (a and $\mathbf{c}$ ) and GPR40 (b and $\mathbf{d}$ ) transcripts were evaluated by real-time PCR in samples collected from the small intestine, liver, white adipose tissue (WAT), frontal cortex, occipital cortex, hippocampus, and hypothalamus (a and $\mathbf{b}$ ) of lean Swiss mice or in samples prepared from the mHypoA 2/29 CLU189 and BV2 cell lines (c and $\mathbf{d}$ ). In e-g, lean Swiss mice were subjected to intracerebroventricular cannulation and treated with a single dose of GW9508 (2.0 $\mu$ l, 1.0 mM); samples were collected after 90 min for the evaluation of GPR120 (E) or GPR40 (g) transcript expression by real-time PCR. In addition, protein samples were utilized in immunoprecipitation experiments using an anti- $\beta$-arrestin-2 antibody; immunoprecipitates were separated by SDS-PAGE, transferred to nitrocellulose membranes, and immunoblotted (IB) with GPR120 or $\beta$-arrestin-2 antibodies (f). In all experiments, $n=5$. In $C$ and $D$, ${ }^{*} p<0.05$ vs. CLU189; in E and $F$, ${ }^{*} p<0.05$ vs. vehicle

curve (AUC) was calculated using these values. For the ipITT, glucose blood levels were sampled $5,10,15,20$, 25 , and 30 min following the intraperitoneal injection of insulin $(0.75 \mathrm{U} / \mathrm{kg})$. The rate constant for glucose disappearance during the insulin tolerance test (Kitt) was calculated using the formula $0.693 / t 1 / 2$. The $t 1 / 2$ for glucose was calculated from the slope of the leastsquares analysis of the plasma glucose concentrations during the linear decay phase [31].

\section{Western blot and immunoprecipitation}

Hypothalamic specimens were homogenized, and samples containing 75-100 mg protein were used as a wholetissue extract in western blot experiments, as previously described [31]. The proteins were separated by sodium dodecyl sulfate-polyacrylamide gel electrophoresis (SDS-
PAGE) transferred to nitrocellulose membranes and blotted with the antibodies indicated, as described in the Results. Specific bands were labeled by chemiluminescence and were quantified by optical densitometry. For immunoprecipitation, hypothalamic lysates $(500 \mu \mathrm{g}$ protein content) were incubated with $1 \mathrm{mg}$ of anti- $\beta$-arrestin-2 antibody overnight at $4{ }^{\circ} \mathrm{C}$, and immune complexes were precipitated with Protein A for $6 \mathrm{~h}$. The samples were then washed with phosphate-buffered solution and were resuspended in sample buffer. Immune complexes were separated by SDS-PAGE, and membranes were blotted with either GPR120 or $\beta$-arrestin-2 antibodies.

\section{RNA extraction and quantitative real-time PCR}

Total RNA was extracted using the commercially available acid-phenol reagent Trizol (Invitrogen Corp.). RNA 


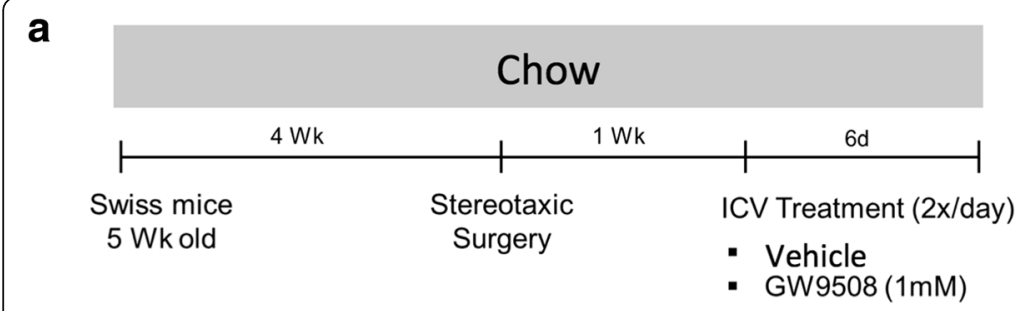

b

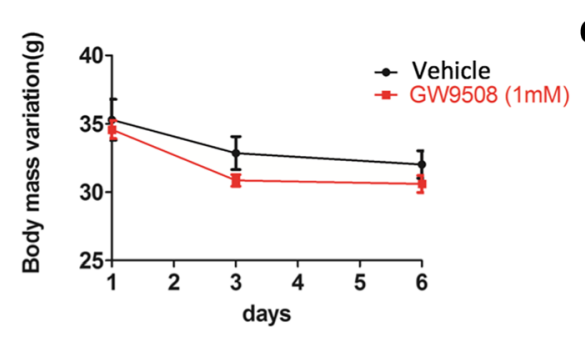

e

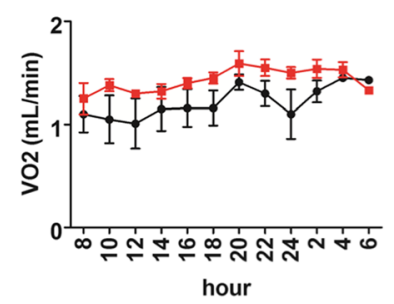

f

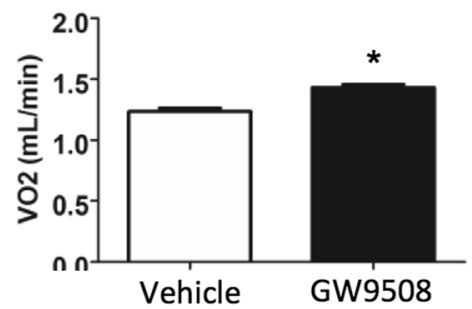

k

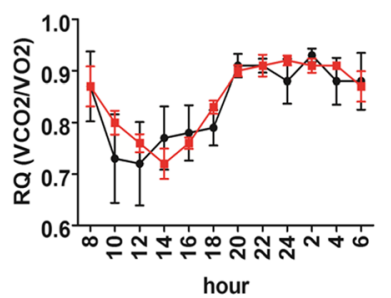

m

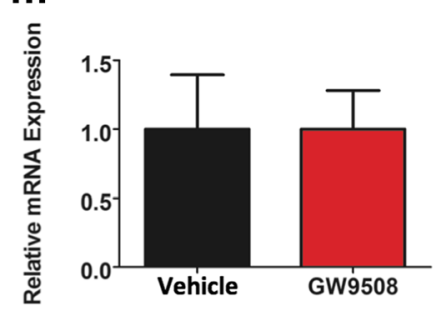

Fig. 5 (See legend on next page.)
C

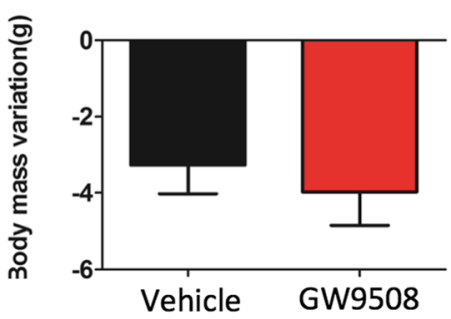

g

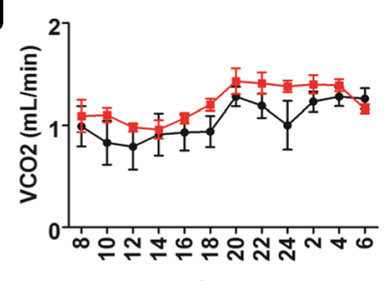

h
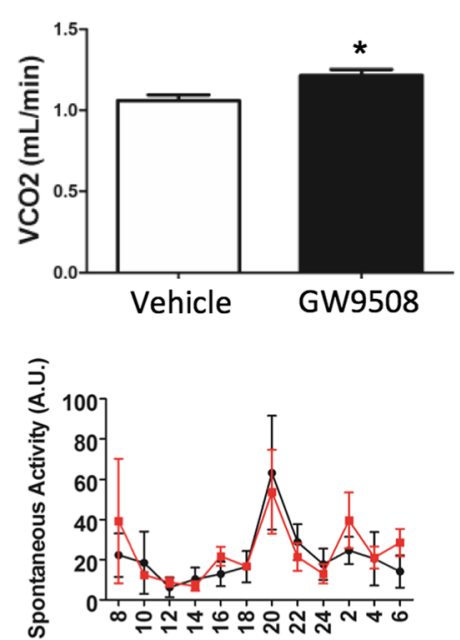

hour d

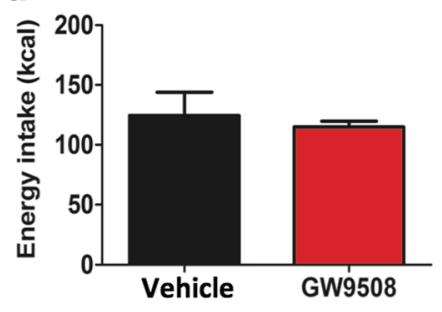

i

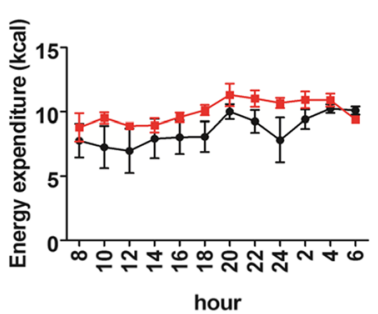

j

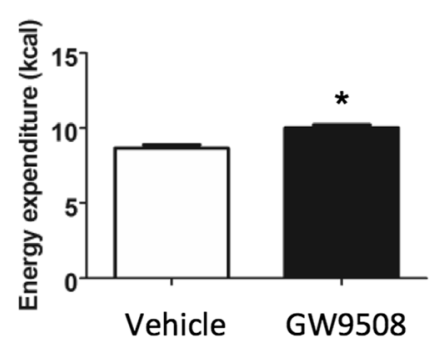

n

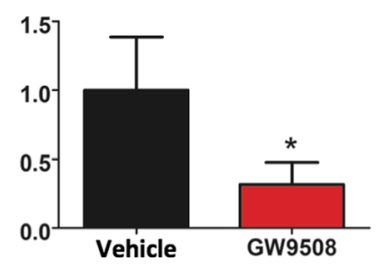

o

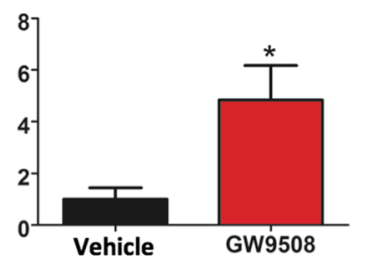

p

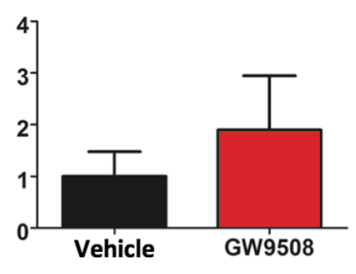


(See figure on previous page.)

Fig. 5 Intracerebroventricular treatment with GW9508 in lean mice. Five-week-old Swiss mice were included in the study and were fed on chow for

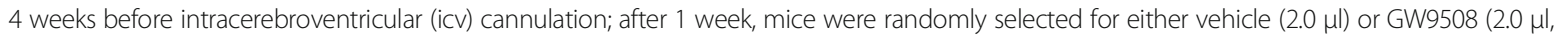
$1.0 \mathrm{mM}$ ) icv treatment twice a day for 6 days (a). Body mass ( $\mathbf{b}$ and $\mathbf{c}$ ) and caloric intake (d) were measured during the experimental period. At the end of the experimental period, some mice were subjected to indirect calorimetry and the determination of spontaneous physical activity, resulting in the values for $\mathrm{O}_{2}$ consumption $(E-F), \mathrm{CO}_{2}$ production $(\mathbf{g}-\mathbf{h})$, energy expenditure $(\mathbf{i}-\mathbf{j})$, respiratory quotient $(\mathbf{k})$, and spontaneous physical activity $(\mathbf{I})$. At the end of the experimental period, the hypothalamus was dissected, and RNA was extracted for real-time PCR determination of transcript levels of TNF- $\alpha(\mathbf{m}), I L 1 \beta(\mathbf{n}), I L 10(\mathbf{o})$, and IL6 (p). In all experiments, $n=5 ;{ }^{*} p<0.05$ vs. vehicle

concentration, purity, and integrity were confirmed spectrophotometrically using a Nanodrop (ND-1000; Nanodrop Technologies, Wilmington, DE). The firststrand cDNA was synthesized using SuperScript III reverse transcriptase and random hexamer primers as described in the manufacturer's protocol (Invitrogen Corp.). Quantitative PCR was run to determine the expression of TNF- $\alpha$, IL1 $\beta$, IL6, IL10, POMC, and NPY in the hypothalamus and to determine the expression of PGC1 $\alpha$, UCP1 and cytochrome $\mathrm{c}$ in the brown adipose tissue using primers supplied with commercially available assays from Applied Biosystems. The reference gene was GAPD. Real-time PCR analysis of gene expression was carried out in an ABI Prism 7500 sequence detection system (Applied Biosystems). For each gene, the optimal concentration of complementary DNA and primers as well as the maximum efficiency of amplification were obtained through 5-point, twofold dilution curve analysis. Amplification was performed in a $20-\mu \mathrm{L}$ final volume containing 40-50 ng of reverse-transcribed RNA according to the manufacturer's recommendations using the TaqMan PCR master mix. Real-time data were analyzed using the Sequence Detector System 1.7 (Applied Biosystems). The results are expressed as relative transcript amounts, as previously optimized [32].

\section{Immunofluorescence staining}

For histological analysis, deep-frozen hypothalamic tissue samples were employed in coronal sectioning $(5.0 \mu \mathrm{m})$. Specimens were double-labeled with either anti-GPR120 or anti-GPR40 antibodies and specific primary antibodies against markers related to the different cell types, including NPY, POMC, Iba1, mannose receptor, vimentin, and IGFBP2. Thereafter, the sections were incubated with specific FITC- or rhodamine-conjugated IgG secondary antibodies and DAPI for nuclear staining. Immunofluorescence imaging was performed to evaluate the distribution of GPR120 and GPR40 in the hypothalamus of the mice. The specificity of the antibodies against GPR120 and GPR40 was evaluated in a separate set of experiments (Additional file 1: Figure S1).

Indirect calorimetry and spontaneous physical activity Oxygen consumption/carbon dioxide production and spontaneous physical activity were measured in fed animals using a computer-controlled, open-circuit calorimeter system (LE405 gas analyzer; Panlab-Harvard Apparatus). Mice were single-housed in clear respiratory chambers, and room air passed through the chambers at a flow rate of ten times the body weight of each animal. The air-flow within each chamber was monitored by a sensor (Air Supply and Switching; Panlab-Harvard Apparatus). Gas sensors were calibrated prior to the onset of experiments with primary gas standards containing known concentrations of $\mathrm{O}_{2}, \mathrm{CO}_{2}$, and $\mathrm{N}_{2}$ (Air Liquid). The analyses were performed over a 24-h period. Outdoor air reference values were sampled after every four measurements. Sample air was sequentially passed through $\mathrm{O}_{2}$ and $\mathrm{CO}_{2}$ sensors for the determination of $\mathrm{O}_{2}$ and $\mathrm{CO}_{2}$ content, from which the measures of oxygen consumption $\left(\mathrm{VO}_{2}\right)$ and carbon dioxide production $\left(\mathrm{VCO}_{2}\right)$ were estimated. The $\mathrm{VO}_{2}$ and $\mathrm{VCO}_{2}$ were calculated by Metabolism version 2.2 software based on the Withers equation and are expressed in milliliters per hour-1 per gram-1. The respiratory quotient was calculated as $\mathrm{VCO}_{2} / \mathrm{VO}_{2}$. Energy expenditure was estimated as $\mathrm{VO}_{2}$ /body mass (grams) [33].

\section{Statistical analysis}

All results are reported as the mean \pm SEM. Differences between the treatment groups were evaluated using an unpaired Student's $t$ test or a one-way analysis of variance (ANOVA). When the ANOVA indicated significance, a Tukey-Kramer post-hoc test was performed (GraphPad Software, San Diego, CA, USA). A $p<0.05$ was accepted as statistically significant.

\section{Results}

\section{The expression of GPR120 and GPR40 in the} hypothalamus of mice

The expression and cellular localization of GPR120 and GPR40 were evaluated in the hypothalamus of male, lean Swiss mice by indirect immunofluorescence staining. As depicted in Fig. 1a-c, the majority of the cells that expressed the microglia marker, mannose receptor, also expressed GPR120 (Fig. 1c). Conversely, we detected no co-localization of GPR120 with either NPY (Fig. 1a) or POMC (Fig. 1b). Figure $2 \mathrm{a}-\mathrm{c}$ shows that the majority of the cells that expressed NPY (Fig. 2a) and POMC (Fig. 2b) also expressed GPR40, whereas the majority of 


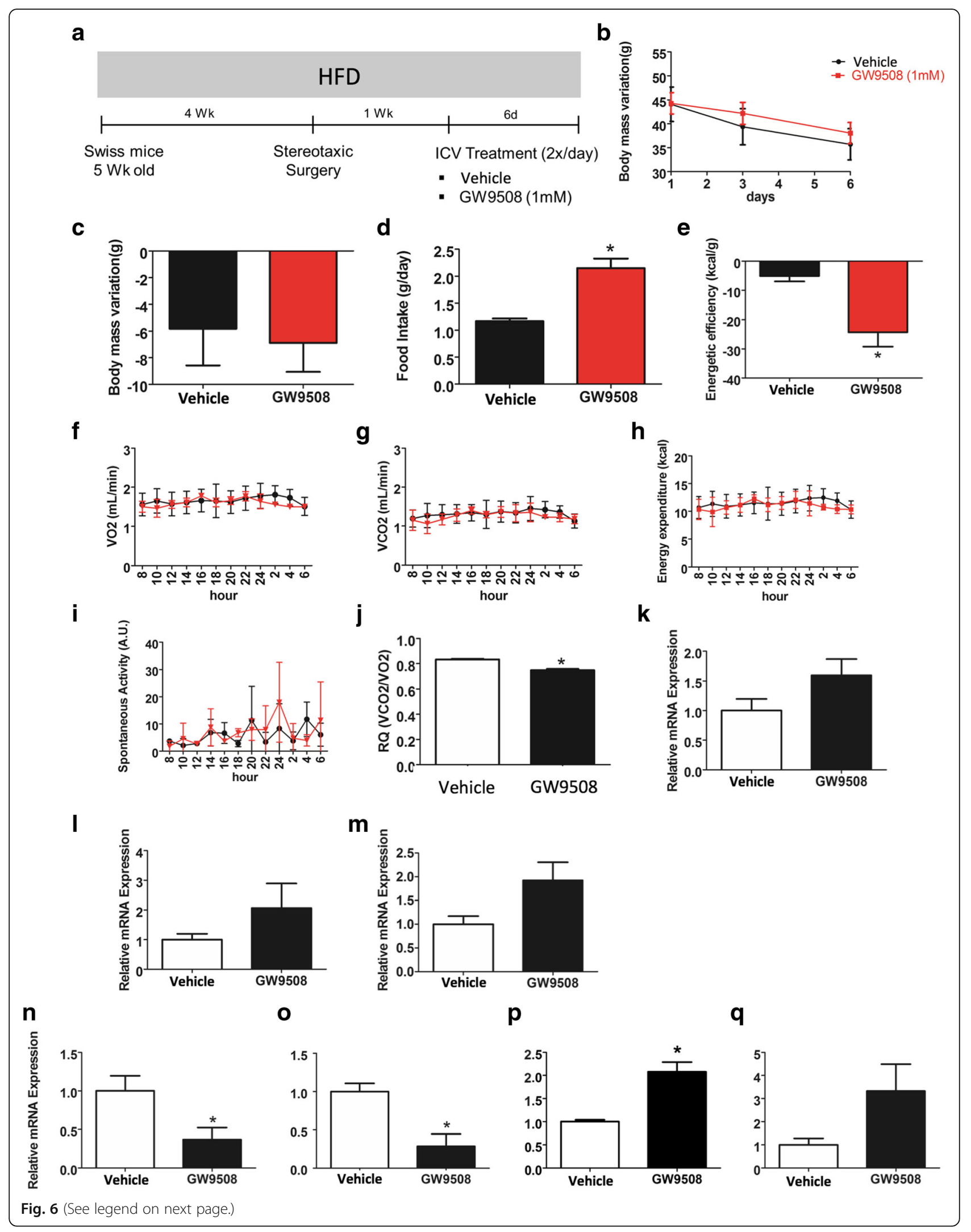




\section{(See figure on previous page.)}

Fig. 6 Intracerebroventricular treatment with GW9508 in obese mice. Five-week-old Swiss mice were included in the study and were fed on a high-fat diet

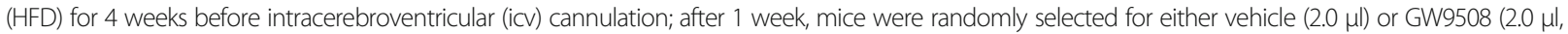
$1.0 \mathrm{mM}$ ) icv treatment twice a day for 6 days (a). Body mass ( $\mathbf{b}$ and $\mathbf{c})$, caloric intake $(\mathbf{d})$, and energy efficiency (e) were measured during the experimental period. At the end of the experimental period, some of the mice were subjected to indirect calorimetry and the determination of spontaneous physical activity, resulting in the values for $\mathrm{O}_{2}$ consumption $(F), \mathrm{CO}_{2}$ production $(\mathbf{g})$, energy expenditure $(\mathbf{h})$, spontaneous physical activity (i), and respiratory quotient (j). RNA samples were obtained from the brown adipose tissue for real-time PCR determination of the transcript expression of UCP1 (k), PGC1a (l), and cytochrome $c(\mathbf{m})$. In addition, the hypothalamus was dissected, and RNA was extracted for real-time PCR determination of the transcript levels of TNF-a (n), IL1 $\beta(\mathbf{o}), I L 10(\mathbf{p})$, and IL6 (q). In all experiments, $n=5 ;{ }^{*} p<0.05$ vs. vehicle

the cells that expressed the microglia marker, Iba1, did not express GPR40 (Fig. 2c). Because of the localization and shape of GPR120-expressing cells (as depicted in Fig. 1) were similar to that described for tanycytes present in the periventricular area [34, 35], we evaluated the potential co-expression of GPR120 with vimentin (Fig. 3a), a general marker of tanycytes, and IGFBP2 (Fig. 3b), a specific marker for $\beta 1$-tanycytes [34, 35]. There was only a minor co-localization of GPR120 and vimentin in the region of the junction between the medium eminence and the arcuate nucleus (Fig. 3a). However, no co-localization was observed between GPR120 and IGFBP2 (Fig. 3c). Next, the relative transcript amounts of both GPR120 and GPR40 were evaluated by real-time PCR in samples from distinct tissues of the body. As depicted in Fig. 4a, GPR120 was predominantly expressed in the intestine and white adipose tissue, whereas its levels were low in the central nervous system and similar across the regions tested: frontal cortex, occipital cortex, hippocampus, and hypothalamus. Conversely, the transcript levels of GPR40 (Fig. 4b) were as high in the hypothalamus as in the intestine, liver, and adipose tissue, whereas in the other brain regions tested, its expression was considerably lower. Finally, we evaluated the expressions of GPR120 (Fig. 4c) and GPR40 (Fig. 4d) transcripts in a hypothalamic neuronal cell line, CLU189 [36], and in a microglial cell line, BV2 [37]. Consistent with the findings in the mice, CLU189 cells expressed higher relative amounts of GPR40 compared to GPR120, whereas the opposite occurred in BV2 cells.

\section{The activation of hypothalamic GPR120 and GPR40 in lean mice}

GW9508 is a synthetic agonist that activates GPR120 and GPR40 with $\mathrm{EC}_{50}$ values of $2.2 \mu \mathrm{M}$ and $47 \mathrm{nM}$, respectively [26]. Upon hypothalamic delivery, GW9508 was not capable of changing GPR120 transcript expression (Fig. 4e) but promoted its activation through the engagement of $\beta$-arrestin-2 (Fig. 4f). In addition, GW9508 stimulated an increase of GPR40 transcript levels (Fig. 4g). Next, we treated lean mice with two daily doses of GW9508-delivered icv for 6 days (Fig. 5a). The treatment did not cause a significant change in body mass (Fig. 5b, c) or in spontaneous caloric intake
(Fig. 5d). However, mice treated with the compound exhibited significantly increased $\mathrm{O}_{2}$ consumption (Fig. 5e, f) and $\mathrm{CO}_{2}$ production (Fig. $5 \mathrm{~g}, \mathrm{~h}$ ), resulting in increased energy expenditure (Fig. 5i, $j$ ) in the absence of any modifications of RQ (Fig. 5k) or spontaneous physical activity (Fig. 5l). Interestingly, icv GW9508 induced a reduction of the hypothalamic expression of IL1 $\beta$ (Fig. 5n) and an increase of IL10 (Fig. 5o), without causing a change in TNF- $\alpha$ (Fig. 5m) or IL6 (Fig. 5p).

\section{The activation of GPR120 and GPR40 in obese mice}

Male Swiss mice were fed on a HFD for 4 weeks and then subjected to icv cannulation for treatment with GW9508 twice a day for 6 days (Fig. 6a). GW9508 produced no change in body mass (Fig. 6b, c) but increased caloric intake (Fig. 6d), resulting in reduced energy efficiency (Fig. 6e). These changes were not accompanied by modifications of $\mathrm{O}_{2}$ consumption (Fig. 6f), $\mathrm{CO}_{2}$ production (Fig. 6g), energy expenditure (Fig. 6h), or spontaneous physical activity (Fig. 6i). However, RQ was reduced (Fig. 6j), and there were trends toward increased expression of UCP1 (Fig. 6k), PGC1 $\alpha$ (Fig. 6l), and cytochrome $\mathrm{c}$ (Fig. $6 \mathrm{~m}$ ) in the brown adipose tissue. Moreover, GW9508 reduced hypothalamic TNF- $\alpha$ (Fig. 6n) and IL1 $\beta$ (Fig. 6o), accompanied by increased IL10 (Fig. 6p) without a change in IL6 (Fig. 6q).

\section{Lentiviral targeting of GPR120 in obese mice}

Lentiviruses harboring five different shRNA sequences were employed in an attempt to inhibit the expression of GPR120. As depicted in Fig. 7a, lentiviruses 1 and 2 (LV1 and LV2) were the most effective in reducing GPR120 expression in CLU189 cells. Bilateral injections of either LV1 or LV2 into the arcuate nucleus (Fig. 7b) resulted in the reduction of GPR120 expression (Fig. 7c). Obese mice were then treated with LV1 via bilateral injection into the arcuate nucleus and followed up for 10 weeks before undergoing icv cannulation for treatment with GW9508 for 6 days (Fig. 7d). During the 10 weeks before GW9508 treatment, mice injected with LV1 presented no changes in body mass (Fig. 7e, f) or caloric intake (Fig. $7 \mathrm{~g}$ ). Glucose and insulin tolerance tests were performed but revealed no differences between the groups (data not shown). Following GW9508 


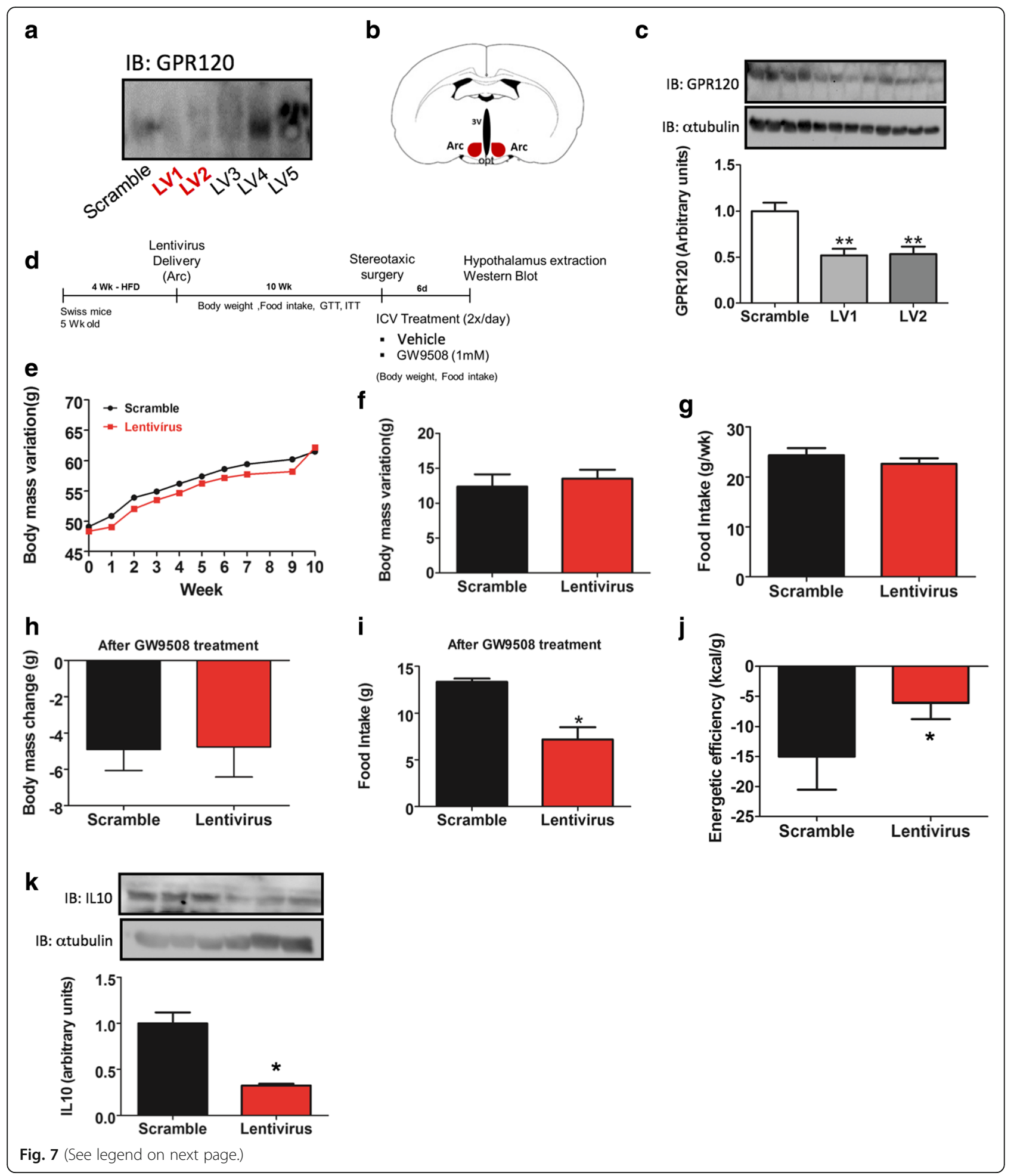


(See figure on previous page.)

Fig. 7 Lentiviral targeting of GPR120. In a, the mHypoA 2/29 CLU189 cell line was transfected with lentivirus containing five distinct (LV1-LV5) sequences of shRNA targeting GPR120 and, in addition, a scrambled control. Protein extracts were prepared and subjected to separation by SDSPAGE, then transferred to a nitrocellulose membrane and blotted with anti-GPR120 antibody. The sequences LV1 and LV2 were utilized in in vivo experiments and were injected bilaterally into the arcuate nucleus (b). 7 days after LV1 or LV2 injection, hypothalami were dissected and used for protein extraction. Samples were subjected to separation by SDS-PAGE, transferred to nitrocellulose membranes and immunoblotted (IB) with an antibody against GPR120 (c). Swiss mice were fed for 4 weeks on a high-fat diet (HFD) and then injected with LV1 or the scrambled control construct into the arcuate nucleus bilaterally; after 10 weeks, the mice were subjected to intracerebroventricular cannulation and following a recovery period of 7 days, subjected to treatment with GW9508 $(2.0 \mu \mathrm{l}, 1.0 \mathrm{mM})$ twice a day for 6 days (d). Body mass (e and $\mathbf{f})$ and caloric intake (g) were determined during the 10 weeks that followed LV1/scramble injection (before GW9508 treatment). Body mass (h), caloric intake (i), and energy efficiency $\mathbf{j}$ ) were evaluated during the 6 days that followed GW9508 treatment. At the end of the experimental period, IL10 protein expression was determined in extracts from the hypothalamus $(\mathbf{k})$. In $\mathbf{c}$ and $\mathbf{k}$, loading controls were obtained by reprobing the membranes with anti-a-tubulin antibody. In $A$, the results are representative of three independent experiments. In $C, n=4 ;{ }^{*} p<0.05$ vs. scramble. In $E-K, n=5 ;{ }^{*} p<0.05$ vs. scramble

treatment, there was no change in body mass (Fig. 7h), but caloric intake was reduced (Fig. 7i), resulting in higher energy efficiency (Fig. 7j). In addition, the hypothalamic expression of IL10 was significantly reduced (Fig. 7k).

\section{The use of specific synthetic agonists of GPR120 and GPR40 in obese mice}

In the last part of the study, we employed two synthetic agonists recently developed to specifically activate either GPR120 or GPR40. TUG1197 activates only GPR120, with a $\mathrm{pEC}_{50}$ of 6.32 (inactive on GPR40), whereas TUG905 activates only GPR40, with a $\mathrm{pEC}_{50}$ of 7.03 (inactive on GPR120) [38]. The capacity of either compound to reduce LPS-induced activation of IKK was determined in CLU189 (Additional file 1: Figure S2A) and BV2 (Additional file 1: Figure S2B) cells in parallel with GW9508. As shown in Additional file 1: Figure S2A and B, TUG905 was effective in reducing IKK activity in either cell type, whereas TUG1197 was capable of reducing IKK activity only in BV2 cells. GW9508 treatment resulted in a trend to reduce the activation of IKK in BV2 $(p=0.07)$ but not in CLU189, probably because of the low expression of GPR120 in this cell line. Next, obese mice were treated icv with either compound for 6 days (Additional file 1: Figure S2C). TUG1197 had no effect on body mass (Additional file 1: Figure S2D) and caloric intake (Additional file 1: Figure S2E); however, it exerted potent anti-inflammatory activity, reducing TNF- $\alpha$ (Additional file 1: Figure S2F) and IL1 $\beta$ (Additional file 1: Figure S2G) while increasing IL10 (Additional file 1: Figure S2H) and IL6 (Additional file 1: Figure S2I) in the hypothalamus. TUG1197 had no significant effect on the expression of NPY (Additional file 1: Figure S2J) and POMC (Additional file 1: Figure S2K). Conversely, TUG905 reduced body mass (Additional file 1: Figure S2D) and exhibited a trend toward reducing caloric intake (Additional file 1: Figure S2E). TUG905 had no effect on TNF- $\alpha$ (Additional file 1: Figure S2F) and IL1 $\beta$ (Additional file 1: Figure S2G) but induced an increase of IL10 (Additional file 1: Figure S2H) and IL6
(Additional file 1: Figure S2I) in the hypothalamus. In addition, TUG905 had no effect on the transcript levels of NPY (Additional file 1: Figure S2J) but increased POMC (Additional file 1: Figure S2K).

\section{Discussion}

The beneficial effects of dietary PUFAs were first reported in epidemiological studies showing that Inuit and Mediterranean populations are protected from cardiovascular disease due to the consumption of fish and olive oil, which are rich in $\omega 3$ and $\omega 9$ PUFAs, respectively [39-41]. Mechanistic studies performed during the last 40 years have shown that at least a portion of the favorable metabolic effects of PUFAs is due to their anti-inflammatory actions. There are different antiinflammatory pathways that can be induced by PUFAs. $\omega 3$ fatty acids can compete with arachidonate for 5-LOX and COX2, which catalyze the synthesis of eicosanoids $[42,43]$. Variations in the rates of $\omega 3$ and $\omega 6$ availability can shift the amounts of the final products of this synthetic pathway [44]. When $\omega 6$ predominates, proinflammatory prostaglandins, leukotrienes, prostacyclins, and thromboxanes are produced [44, 45]. Conversely, upon preferential $\omega 3$ availability, the resulting eicosanoids, including protectins, resolvins, and lipoxins, are either less pro-inflammatory or are anti-inflammatory [44-46]. Transcriptional regulation is yet another mechanism underlying the anti-inflammatory actions of PUFAs [47]. DHA can activate PPAR $\gamma$, leading to the inhibition of inflammatory gene expression [48]. In addition, PPAR $\gamma$ can also inhibit NFKB activity by inducing the expression of ІкB $\alpha$ [49].

More recently, new anti-inflammatory mechanisms have been attributed to PUFAs. These findings emerged mostly due to the work exploring the properties of the previously orphan receptors, GPR120, and GPR40 [20, 25]. Because of the potential use of agonists for these receptors as therapeutic tools for metabolic diseases, we decided to evaluate their presence and action in the hypothalamus of obese rodents. 


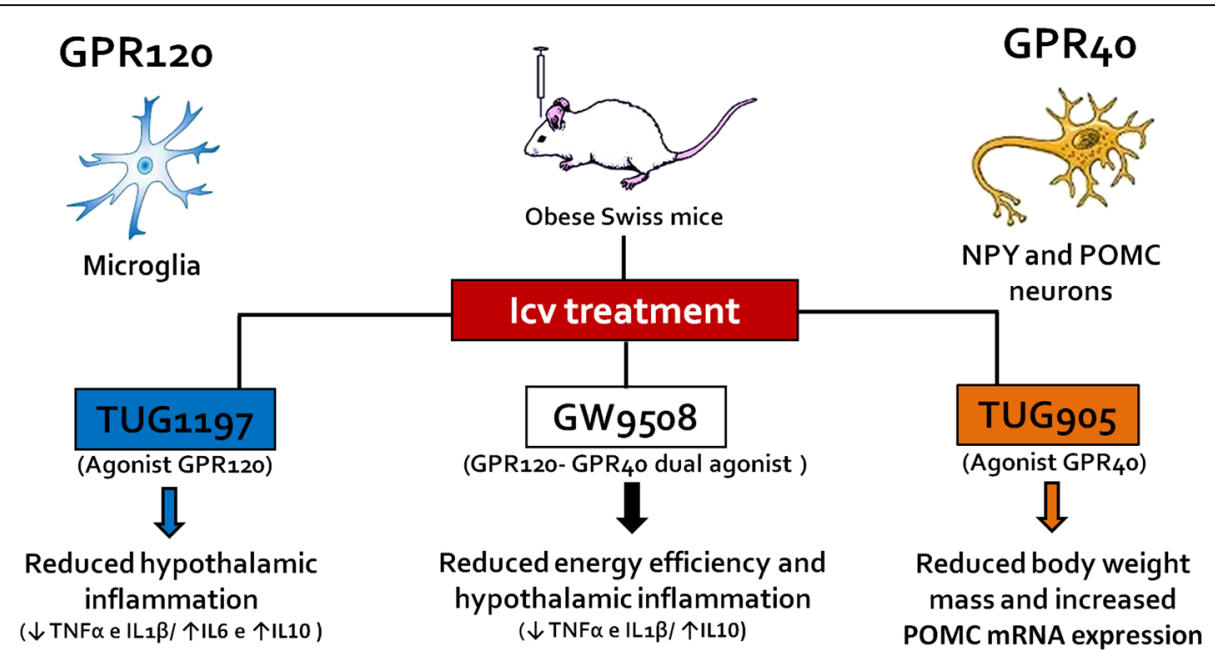

Fig. 8 Schematic representation of the main findings of this study. GPR120 and GPR40 are expressed in the hypothalamus of mice; GPR120 is expressed predominantly in microglia whereas GPR40 is expressed predominantly in POMC and NPY neurons. The intracerebroventricular (icv) injection of agonists in mice results in a number of phenotypic changes. TUG1197, the GPR120 agonist, acts predominantly reducing hypothalamic inflammation. TUG905, the GPR40 agonist, acts predominantly reducing body mass and increasing the expression of the anorexigenic precursor, POMC. The use of a compound that acts simultaneously on GPR120 and GPR40, GW9508, results in the best metabolic outcomes, reducing body mass, improving glucose tolerance and reducing hypothalamic inflammation

Studies have shown that the consumption of dietary fats, particularly long-chain saturated fatty acids, induces the activation of site-specific inflammation in the hypothalamus [32, 50-54]. At least three distinct mechanisms seem to be involved in the activation of the inflammatory response: TLR4 activation, PKC-theta activation and ERS [32, 50-55]. Pharmacological and genetic approaches used to dampen the inflammation mediated by each of these mechanisms have produced encouraging results with respect to the control of body adiposity and whole-body metabolism [32, 50-55]. Previously, we have shown that PUFAs in the diet or injected directly into the hypothalamus can reduce hypothalamic inflammation and can improve the metabolic phenotype [19]. In addition, PUFAs can induce hypothalamic neurogenesis of predominantly POMC neurons [56]. With these results in mind, we hypothesized that at least a portion of the effects of PUFAs in the hypothalamus could be mediated by GPR120 and GPR40.

Accordingly, in the first part of the study, we showed that both receptors are expressed in the hypothalamus. GPR40 levels were considerably higher than GPR120 levels and were similar to the levels expressed in peripheral tissues, such as adipose tissue, intestine, and the liver. Previous studies have reported the presence of high levels of GPR40 in the brain [25]; however, the majority of the work has been focused on the characterization of its role in hippocampal neurogenesis $[28,57]$. There is one previous study showing that GPR40 is present in neurons of the hypothalamus, but the type of neuron was not explored [58]. The study showed an involvement of hypothalamic GPR40 in the response to inflammatory chronic pain [58]. In addition, we showed that inhibiting hypothalamic GPR40 reduces PUFAinduced neurogenesis [56]. Here, we confirmed that GPR40 is present predominantly in hypothalamic neurons, and we expanded this characterization by demonstrating that both NPY and POMC neurons express the highest levels of this receptor.

Regarding GPR120, we showed that it is also present in the hypothalamus; however, the levels of transcript were much lower than in peripheral tissues involved in metabolic activity, such as intestine and adipose tissue [59]. Nevertheless, the levels in the hypothalamus were not that different from the levels in other regions of the brain. The fact that most hypothalamic GPR120 is expressed in microglia may explain why the expression levels were in general quite low. One interesting aspect of the immunofluorescence studies used to characterize the cellular distribution of GPR120 is the fact that some cells expressing GPR120 in the periventricular region nearby the interface between the medium eminence and the arcuate nucleus presented projections in a shape very similar to tanycytes $[34,35]$. Because of that, we performed staining with vimentin, which is expressed in different types of tanycytes and IGFBP2, which is expressed in $\beta 1$-tanycytes. Our results showed only a limited co-localization of GPR120 with vimentin, and, as compared with the staining for mannose receptor, we can conclude that most of GPR120 is expressed in microglia. Our group has published the only previous study reporting the presence of GPR120 in the 
hypothalamus; however, in that study, we did not explore its cellular distribution or its functional relevance [19]. Another study has shown that GPR120 is expressed in a hypothalamic neuronal cell line and can control inflammation [60].

We initially used a non-specific agonist, GW9508, to evaluate the impact of combined GPR120/GPR40 activation in the hypothalamus. There were few differences in the final outcomes of GW9508 treatment when comparing lean versus obese mice, but as a rule, there were improvements in both inflammatory and metabolic parameters. The impact on the regulation of body mass was not as impressive as the effects obtained when other anti-inflammatory approaches are used to dampen obesity-induced hypothalamic inflammation, such as the inhibition of JNK [50], IKK [54], TLR4 [51], or ERS [52]. In fact, the mild effect obtained with the use of GW9508 is consistent with the fact that reducing GPR120 expression with lentivirus-delivered shRNA also resulted in mild phenotypic changes.

As an attempt to define the specific actions of GPR120 and GPR40 in the hypothalamus, we employed two recently developed compounds that exhibit no crossactivity between these receptors. TUG905 acts on GPR40 only, and upon icv treatment, it produced changes predominantly in energy homeostasis, reducing body mass even in the absence of changes in caloric intake. Interestingly, TUG905 increased the levels of POMC without changing the expression of NPY. At first, this could seem unexpected because the majority of the expression of GPR40 in the hypothalamus is found in NPY neurons; however, it has been shown that NPY neurons can modulate POMC production through a plastic connectivity system [61-63].

Conversely, the action of TUG1197 on GPR120 produced no change in caloric intake and body mass but reduced hypothalamic inflammation. Considering that reductions of body adiposity have been observed in other studies that used approaches that acted solely on the inflammatory aspect of the hypothalamic dysfunction in obesity [32, 50-54], one could ask why this did not happen with TUG1197. In our opinion, there are two possibilities: either (i) the magnitude of the antiinflammatory effect was not sufficient to modify energy homeostasis; or (ii) 6 days of treatment was not sufficient to observe the putative ongoing changes in the control of energy homeostasis.

Regardless of the answer, we conclude that both GPR120 and GPR40 are expressed in the hypothalamus, and the combined activation of both receptors results in benefits for the control of whole-body energy homeostasis and hypothalamic inflammation. We propose that at least a portion of the metabolic benefits obtained with the consumption of PUFAs may be due to the activation of hypothalamic receptors.

\section{Conclusions}

We show that both receptors are expressed in the hypothalamus; GPR120 is primarily present in microglia, whereas GPR40 is expressed in neurons. We conclude that GPR120 and GPR40 act in concert in the hypothalamus to reduce energy efficiency and to regulate the inflammation associated with obesity. The combined activation of both receptors in the hypothalamus results in better metabolic outcomes than the isolated activation of either receptor alone. Figure 8 presents a schematic view of the main findings of this study.

\section{Additional file}

Additional file 1: Figure S1. Testing the specificity of the antibodies against GPR120 and GPR40. Figure S2 specific activation of GPR120 and GPR40. (PDF $10063 \mathrm{~kb}$ )

\section{Acknowledgements}

We thank Erika Roman, Joseane Morari, Lucas F. Nascimento, Gerson Ferraz, and Marcio Cruz from the University of Campinas for their technical assistance.

\section{Funding}

Support for this study was provided by Fundação de Amparo a Pesquisa do Estado de São Paulo and Conselho Nacional de Desenvolvimento Cientifico e Tecnológico. The Laboratory of Cell Signaling belongs to the Obesity and Comorbidities Research Center and the National Institute of Science and

Technology-Diabetes and Obesity.

Availability of data and materials

All raw data used in this manuscript are available on request.

Authors' contributions

VLA and DNRV designed the studies. DNRV, SC, RAF, MRF, and RDS performed the various experiments. UT, CE, and AC synthesized TUG905 and TUG1197. All authors contributed to the writing and editing of the manuscript. All authors read and approved the final manuscript.

Consent for publication

Not applicable

\section{Competing interests}

The authors declare that they have no competing interests.

\section{Ethics approval}

The investigation was conducted in accordance with the principles and procedures described by the National Institutes of Health Guidelines for the Care and Use of Experimental Animals and was previously approved by the University of Campinas Ethical Committee (ID 2011/2327-1)

\section{Publisher's Note}

Springer Nature remains neutral with regard to jurisdictional claims in published maps and institutional affiliations.

\section{Author details}

${ }^{1}$ Laboratory of Cell Signaling and Obesity and Comorbidities Research Center, University of Campinas, Campinas, SP 13084-970, Brazil. ²Department of Physics, Chemistry and Pharmacy, University of Southern Denmark, DK-5230 Odense, Denmark. ${ }^{3}$ Laboratory of Cell Signaling, University of Campinas, Rua Cinco de Junho, 350, Cidade Universitária, Campinas, SP 13083-877, Brazil. 
Received: 13 July 2016 Accepted: 20 April 2017 Published online: 26 April 2017

\section{References}

1. Hotamisligil GS. Inflammation and endoplasmic reticulum stress in obesity and diabetes. Int J Obes (Lond). 2008;32 Suppl 7:S52-54.

2. Hill JO, Peters JC. Environmental contributions to the obesity epidemic. Science. 1998;280:1371-4.

3. Flier JS. Obesity wars: molecular progress confronts an expanding epidemic. Cell. 2004;116:337-50.

4. Shi H, Kokoeva MV, Inouye K, Tzameli I, Yin H, Flier JS. TLR4 links innate immunity and fatty acid-induced insulin resistance. J Clin Invest. 2006;116:3015-25.

5. Velloso LA, Eizirik DL, Cnop M. Type 2 diabetes mellitus-an autoimmune disease? Nat Rev Endocrinol. 2013;9:750-5.

6. Osborn O, Olefsky JM. The cellular and signaling networks linking the immune system and metabolism in disease. Nat Med. 2012;18:363-74.

7. Velloso LA, Schwartz MW. Altered hypothalamic function in diet-induced obesity. Int J Obes (Lond). 2011;35:1455-65.

8. Eizirik DL, Cardozo AK, Cnop M. The role for endoplasmic reticulum stress in diabetes mellitus. Endocr Rev. 2008;29:42-61.

9. Cnop M, Foufelle F, Velloso LA. Endoplasmic reticulum stress, obesity and diabetes. Trends Mol Med. 2012;18:59-68.

10. Samuel VT, Shulman Gl. Mechanisms for insulin resistance: common threads and missing links. Cell. 2012;148:852-71.

11. Purkayastha S, Zhang G, Cai D. Uncoupling the mechanisms of obesity and hypertension by targeting hypothalamic IKK-beta and NF-kappaB. Nat Med. 2011;17:883-7.

12. Zhang G, Li J, Purkayastha S, Tang Y, Zhang H, Yin Y, Li B, Liu G, Cai D. Hypothalamic programming of systemic ageing involving IKK-beta, NFkappaB and GnRH. Nature. 2013;497:211-6.

13. Donath MY, Shoelson SE. Type 2 diabetes as an inflammatory disease. Nat Rev Immunol. 2011;11:98-107.

14. Gregor MF, Hotamisligil GS. Inflammatory mechanisms in obesity. Annu Rev Immunol. 2011;29:415-45.

15. McNelis JC, Olefsky JM. Macrophages, immunity, and metabolic disease. Immunity. 2014;41:36-48.

16. Goldfine AB, Fonseca V, Jablonski KA, Chen YD, Tipton L, Staten MA Shoelson SE. Targeting inflammation using salsalate in type 2 diabetes study t: salicylate (salsalate) in patients with type 2 diabetes: a randomized trial. Ann Intern Med. 2013;159:1-12.

17. Nagasumi K, Esaki R, Iwachidow K, Yasuhara Y, Ogi K, Tanaka H, Nakata M, Yano T, Shimakawa K, Taketomi S, et al. Overexpression of GPR40 in pancreatic betacells augments glucose-stimulated insulin secretion and improves glucose tolerance in normal and diabetic mice. Diabetes. 2009;58:1067-76.

18. Oh DY, Talukdar S, Bae EJ, Imamura T, Morinaga H, Fan W, Li P, Lu WJ, Watkins SM, Olefsky JM. GPR120 is an omega-3 fatty acid receptor mediating potent anti-inflammatory and insulin-sensitizing effects. Cell. 2010;142:687-98.

19. Cintra DE, Ropelle ER, Moraes JC, Pauli JR, Morari J, Souza CT, Grimaldi R, Stahl M, Carvalheira JB, Saad MJ, Velloso LA. Unsaturated fatty acids revert dietinduced hypothalamic inflammation in obesity. PLoS One. 2012;7:e30571.

20. Itoh Y, Kawamata Y, Harada M, Kobayashi M, Fujii R, Fukusumi S, Ogi K, Hosoya M, Tanaka $Y$, Uejima $H$, et al. Free fatty acids regulate insulin secretion from pancreatic beta cells through GPR40. Nature. 2003;422:173-6.

21. Oh DY, Olefsky JM. Omega 3 fatty acids and GPR120. Cell Metab. 2012;15:564-5.

22. da Oh Y, Walenta E, Akiyama TE, Lagakos WS, Lackey D, Pessentheiner AR, Sasik R, Hah N, Chi TJ, Cox JM, et al. A Gpr120-selective agonist improves insulin resistance and chronic inflammation in obese mice. Nat Med. 2014; 20:942-7.

23. Ichimura A, Hasegawa S, Kasubuchi M, Kimura I. Free fatty acid receptors as therapeutic targets for the treatment of diabetes. Front Pharmacol. 2014;5:236.

24. Burant CF. Activation of GPR40 as a therapeutic target for the treatment of type 2 diabetes. Diabetes Care. 2013;36 Suppl 2:S175-179.

25. Briscoe CP, Tadayyon M, Andrews JL, Benson WG, Chambers JK, Eilert MM, Ellis C, Elshourbagy NA, Goetz AS, Minnick DT, et al. The orphan G proteincoupled receptor GPR40 is activated by medium and long chain fatty acids. J Biol Chem. 2003;278:11303-11.

26. Briscoe CP, Peat AJ, McKeown SC, Corbett DF, Goetz AS, Littleton TR, McCoy DC, Kenakin TP, Andrews JL, Ammala C, et al. Pharmacological regulation of insulin secretion in MIN6 cells through the fatty acid receptor GPR40: identification of agonist and antagonist small molecules. Br J Pharmacol. 2006;148:619-28.

27. Edfalk S, Steneberg P, Edlund H. Gpr40 is expressed in enteroendocrine cells and mediates free fatty acid stimulation of incretin secretion. Diabetes. 2008;57:2280-7.

28. Boneva NB, Yamashima T. New insights into "GPR40-CREB interaction in adult neurogenesis" specific for primates. Hippocampus. 2012;22:896-905.

29. Christiansen E, Due-Hansen ME, Urban C, Grundmann M, Schroder R, Hudson BD, Milligan G, Cawthorne MA, Kostenis E, Kassack MU, Ulven T. Free fatty acid receptor 1 (FFA1/GPR40) agonists: mesylpropoxy appendage lowers lipophilicity and improves ADME properties. J Med Chem. 2012;55:6624-8.

30. Azevedo CM, Watterson KR, Wargent ET, Hansen SV, Hudson BD, Kepczynska MA, Dunlop J, Shimpukade B, Christiansen E, Milligan G, et al. Non-acidic free fatty acid receptor 4 agonists with antidiabetic Activity. J Med Chem. 2016:59:8868-78.

31. Dragano NR, Marques A, Cintra DE, Solon C, Morari J, Leite-Legatti AV, Velloso LA, Marostica-Junior MR. Freeze-dried jaboticaba peel powder improves insulin sensitivity in high-fat-fed mice. Br J Nutr. 2013;110:447-55.

32. Morari J, Anhe GF, Nascimento LF, de Moura RF, Razolli D, Solon C, Guadagnini D, Souza G, Mattos AH, Tobar N, et al. Fractalkine (CX3CL1) is involved in the early activation of hypothalamic inflammation in experimental obesity. Diabetes. 2014;63:3770-84.

33. Razolli DS, Moraes JC, Morari J, Moura RF, Vinolo MA, Velloso LA. TLR4 expression in bone marrow-derived cells is both necessary and sufficient to produce the insulin resistance phenotype in diet-induced obesity. Endocrinology. 2015;156:103-13.

34. Goodman T, Hajihosseini MK. Hypothalamic tanycytes-masters and servants of metabolic, neuroendocrine, and neurogenic functions. Front Neurosci. 2015;9:387.

35. Balland E, Dam J, Langlet F, Caron E, Steculorum S, Messina A, Rasika S, Falluel-Morel A, Anouar Y, Dehouck B, et al. Hypothalamic tanycytes are an ERK-gated conduit for leptin into the brain. Cell Metab. 2014;19:293-301.

36. Chalmers JA, Jang JJ, Belsham DD. Glucose sensing mechanisms in hypothalamic cell models: glucose inhibition of AgRP synthesis and secretion. Mol Cell Endocrinol. 2014;382:262-70.

37. Henn A, Lund S, Hedtjarn M, Schrattenholz A, Porzgen P, Leist M. The suitability of BV2 cells as alternative model system for primary microglia cultures or for animal experiments examining brain inflammation. ALTEX. 2009;26:83-94.

38. Hudson BD, Shimpukade B, Mackenzie AE, Butcher AJ, Pediani JD, Christiansen E, Heathcote H, Tobin AB, Ulven T, Milligan G. The pharmacology of TUG-891, a potent and selective agonist of the free fatty acid receptor 4 (FFA4/GPR120), demonstrates both potential opportunity and possible challenges to therapeutic agonism. Mol Pharmacol. 2013;84:710-25.

39. Burr ML, Fehily AM, Gilbert JF, Rogers S, Holliday RM, Sweetnam PM, Elwood PC, Deadman NM. Effects of changes in fat, fish, and fibre intakes on death and myocardial reinfarction: diet and reinfarction trial (DART). Lancet. 1989;2:757-61.

40. Bjerregaard P, Mulvad G, Pedersen HS. Cardiovascular risk factors in Inuit of Greenland. Int J Epidemiol. 1997;26:1182-90.

41. Estruch R, Ros E, Salas-Salvado J, Covas MI, Corella D, Aros F, Gomez-Gracia E, Ruiz-Gutierrez V, Fiol M, Lapetra J, et al. Primary prevention of cardiovascular disease with a Mediterranean diet. N Engl J Med. 2013;368: 1279-90.

42. Fischer $\mathrm{S}$, Weber PC. Prostaglandin $\mathrm{I} 3$ is formed in vivo in man after dietary eicosapentaenoic acid. Nature. 1984;307:165-8.

43. Serhan CN, Clish CB, Brannon J, Colgan SP, Chiang N, Gronert K. Novel functional sets of lipid-derived mediators with antiinflammatory actions generated from omega-3 fatty acids via cyclooxygenase 2-nonsteroidal antiinflammatory drugs and transcellular processing. J Exp Med. 2000;192:1197-204.

44. Schmitz G, Ecker J. The opposing effects of $n-3$ and $n-6$ fatty acids. Prog Lipid Res. 2008;47:147-55.

45. Serhan CN, Chiang N, Van Dyke TE. Resolving inflammation: dual antiinflammatory and pro-resolution lipid mediators. Nat Rev Immunol. 2008;8: 349-61.

46. Serhan CN. Pro-resolving lipid mediators are leads for resolution physiology. Nature. 2014;510:92-101

47. Sampath $\mathrm{H}, \mathrm{Ntambi} J \mathrm{M}$. Polyunsaturated fatty acid regulation of gene expression. Nutr Rev. 2004;62:333-9.

48. Wolfrum C, Borchers T, Sacchettini JC, Spener F. Binding of fatty acids and peroxisome proliferators to orthologous fatty acid binding proteins from human, murine, and bovine liver. Biochemistry. 2000;39:1469-74. 
49. Delerive P, Gervois P, Fruchart JC, Staels B. Induction of IkappaBalpha expression as a mechanism contributing to the anti-inflammatory activities of peroxisome proliferator-activated receptor-alpha activators. J Biol Chem. 2000;275:36703-7.

50. De Souza CT, Araujo EP, Bordin S, Ashimine R, Zollner RL, Boschero AC, Saad MJ, Velloso LA. Consumption of a fat-rich diet activates a proinflammatory response and induces insulin resistance in the hypothalamus. Endocrinology. 2005;146:4192-9.

51. Milanski M, Degasperi G, Coope A, Morari J, Denis R, Cintra DE, Tsukumo DM, Anhe G, Amaral ME, Takahashi HK, et al. Saturated fatty acids produce an inflammatory response predominantly through the activation of TLR4 signaling in hypothalamus: implications for the pathogenesis of obesity. J Neurosci. 2009;29:359-70.

52. Ozcan L, Ergin AS, Lu A, Chung J, Sarkar S, Nie D, Myers Jr MG, Ozcan U. Endoplasmic reticulum stress plays a central role in development of leptin resistance. Cell Metab. 2009;9:35-51.

53. Thaler JP, Yi CX, Schur EA, Guyenet SJ, Hwang BH, Dietrich MO, Zhao X, Sarruf DA, Izgur V, Maravilla KR, et al. Obesity is associated with hypothalamic injury in rodents and humans. J Clin Invest. 2012;122:153-62

54. Zhang X, Zhang G, Zhang H, Karin M, Bai H, Cai D. Hypothalamic IKKbeta/ NF-kappaB and ER stress link overnutrition to energy imbalance and obesity. Cell. 2008;135:61-73.

55. Benoit SC, Kemp CJ, Elias CF, Abplanalp W, Herman JP, Migrenne S, Lefevre AL, Cruciani-Guglielmacci C, Magnan C, Yu F, et al. Palmitic acid mediates hypothalamic insulin resistance by altering PKC-theta subcellular localization in rodents. J Clin Invest. 2009:119:2577-89.

56. Nascimento LF, Souza GF, Morari J, Barbosa GO, Solon C, Moura RF, Victorio SC, Ignacio-Souza LM, Razolli DS, Carvalho HF, Velloso LA. n-3 fatty acids induce neurogenesis of predominantly POMC-expressing cells in the hypothalamus. Diabetes. 2016;65:673-86.

57. Ma D, Lu L, Boneva NB, Warashina S, Kaplamadzhiev DB, Mori Y, Nakaya MA, Kikuchi $M$, Tonchev $A B$, Okano $H$, Yamashima T. Expression of free fatty acid receptor GPR40 in the neurogenic niche of adult monkey hippocampus. Hippocampus. 2008;18:326-33.

58. Nakamoto K, Nishinaka T, Sato N, Mankura M, Koyama Y, Kasuya F, Tokuyama S. Hypothalamic GPR40 signaling activated by free long chain fatty acids suppresses CFA-induced inflammatory chronic pain. PLoS One. 2013;8:e81563.

59. Hirasawa A, Tsumaya K, Awaji T, Katsuma S, Adachi T, Yamada M, Sugimoto Y, Miyazaki S, Tsujimoto G. Free fatty acids regulate gut incretin glucagonlike peptide-1 secretion through GPR120. Nat Med. 2005;11:90-4.

60. Wellhauser $L$, Belsham DD. Activation of the omega-3 fatty acid receptor GPR120 mediates anti-inflammatory actions in immortalized hypothalamic neurons. J Neuroinflammation. 2014;11:60.

61. Horvath TL, Sarman B, Garcia-Caceres C, Enriori PJ, Sotonyi P, Shanabrough M, Borok E, Argente J, Chowen JA, Perez-Tilve D, et al. Synaptic input organization of the melanocortin system predicts diet-induced hypothalamic reactive gliosis and obesity. Proc Natl Acad Sci U S A. 2010; 107:14875-80

62. Bell ME, Bhatnagar S, Akana SF, Choi S, Dallman MF. Disruption of arcuate/ paraventricular nucleus connections changes body energy balance and response to acute stress. J Neurosci. 2000;20:6707-13.

63. Dietrich MO, Antunes C, Geliang G, Liu ZW, Borok E, Nie Y, Xu AW, Souza DO, Gao Q, Diano S, et al. Agrp neurons mediate Sirt1's action on the melanocortin system and energy balance: roles for Sirt1 in neuronal firing and synaptic plasticity. J Neurosci. 2010;30:11815-25.

\section{Submit your next manuscript to BioMed Central and we will help you at every step:}

- We accept pre-submission inquiries

- Our selector tool helps you to find the most relevant journal

- We provide round the clock customer support

- Convenient online submission

- Thorough peer review

- Inclusion in PubMed and all major indexing services

- Maximum visibility for your research

Submit your manuscript at www.biomedcentral.com/submit
Biomed Central 